\section{Higher Renovation Pruning Height Improves Early Yields of 'Woodard' Rabbiteye Blueberry}

\author{
Eric T. Stafne ${ }^{1}$ and Barbara J. Smith ${ }^{2}$
}

\begin{abstract}
AdDITIONAL INDEX wORDs. growth index, harvest index, phosphorous acid, rejuvenation, Vaccinium virgatum

SUMMARY. Rabbiteye blueberry (Vaccinium virgatum) bushes are relatively easy to grow and commonplace across Mississippi; however, if not properly maintained, the bushes will decline over time. Eighteen, aged, low-productivity 'Woodard' rabbiteye blueberry bushes were pruned at two different heights (ground level and a $50-\mathrm{cm}$ above ground level) after harvest in July 2017, and phosphorous acid was applied as a drench and foliar spray in the first year, but this was discontinued as the applications had no effect on the bushes. For two seasons, fruit yields were collected and weighed, bushes were measured for growth parameters, and canes were weighed. Bushes pruned at the $50-\mathrm{cm}$ above ground level had much higher yields in both 2019 (3.47 vs. $0.63 \mathrm{~kg}$ ) and 2020 (3.91 vs. $1.23 \mathrm{~kg}$ ), thus providing a substantial yield benefit. The $50-\mathrm{cm}$ above ground level pruning treatment bushes produced more canes by the end of the study, therefore accounting for more fruiting area, as seen in the harvest index. In short, pruning old, nonproductive bushes at a $50-\mathrm{cm}$ above ground level can provide growers with greater potential for early economic returns than pruning at ground level, for 'Woodard' rabbiteye blueberry.
\end{abstract}

$\mathrm{R}$ abbiteye blueberry (Vaccinium virgatum) bushes can live for many years, but if they are not well maintained they can lose vigor and fruiting productivity (Stafne et al., 2020). Renovation

$\overline{\text { Received for publication } 21 \text { Dec. 2020. Accepted for }}$ publication 27 Jan. 2021.

Published online 23 February 2021.

${ }^{1}$ South Branch Experiment Station, Coastal Research and Extension Center, Mississippi State University, 810 Hwy 26 West, Poplarville, MS 39470

${ }^{2}$ U.S. Department of Agriculture, Agricultural Research Service, Thad Cochran Southern Horticultural Laboratory, 810 Hwy 26 West, Poplarville, MS 39470

The project was founded through a Specific Cooperative Agreement between Mississippi State University and the U.S. Department of Agriculture, Agricultural Research Service (USDA-ARS), supported by the Mississippi Agricultural, Forestry and Experiment Station and Mississippi State University Extension Service. This material is based on work that is supported by the National Institute of Food and Agriculture, USDA, Hatch project 1014723, MIS149192. The use of trade, firm, or corporation names in this publication is for the information and convenience of the reader. Such use does not constitute an official endorsement or approval by Mississippi State University or the USDA or the ARS, or of any product or service to the exclusion of others that may be suitable.

We gratefully acknowledge the technical support of M. Miller-Butler, J.B. Carroll, R. Davis, O. Mavrodi, and $\mathrm{H}$. Williams. Additionally, we wish to recognize the reviewers of the initial drafts of this manuscript: R.A. Melanson, M. Miller-Butler, and H. Sakhanokho.

E.T.S. is the corresponding author. E-mail: eric. stafne@msstate.edu.

This is an open access article distributed under the $\mathrm{CC}$ BY-NC-ND license (https://creativecommons.org/ licenses/by-nc-nd/4.0/).

https://doi.org/10.21273/HORTTECH04782-20 pruning is a way to re-invigorate bushes by severely cutting back old growth to promote flushes of new canes that lead to more fruit-bearing potential. Producers who purchase old rabbiteye blueberry plantings often have questions on how best to rejuvenate bushes, including how much to cut off and when fruit will be harvested again. In much of the southeastern United States, mature bushes are sheared or topped immediately after harvest each year, which allows sufficient time for cane regrowth and fruiting bud development during the remaining summer period. While this is a common practice on rabbiteye blueberry bushes, a more radical pruning (renovation) is sometimes required to re-invigorate moribund and poorly maintained plantings of highbush blueberry [ $\mathrm{Vac}^{-}$ cinium corymbosum (Longstroth, 2015)] and rabbiteye blueberry (Austin and Brightwell, 1984). When renovation pruning is performed, blueberry bushes are pruned to the ground or close to the ground, resulting in no fruit production the following year or perhaps even longer. However, if plants recover quicker, then an earlier harvestable crop could be gained to offset the costs of the renovation process.

Phosphorous acid, or phosphite, is a reduced form of phosphate and is often marketed as a fungicide that may also have other plant health-inducing or biostimulant properties. Phosphite has been reported to reduce plant stress and thereby indirectly improve yields and fruit quality. Woody fruit crops, such as avocado (Persea americana) and citrus (Citrus sp.) (Lovatt, 1999, 2013) and peach (Prunus persica) and red raspberry (Rubus idaeus) (Rickard, 2000), have been studied; however, there are conflicting reports on why phosphite application may be effective in improving plant productivity (GomezMerino and Trejo-Tellez, 2015; Thao and Yamakawa, 2009). The potential of this type of application in rabbiteye blueberry has not been explored as it has in other crops.

The purpose of this study was to determine how renovation pruning height affects rabbiteye blueberry plant growth, fruit quality, and total yield in the second and third growing seasons after treatment and combined across first-year phosphite applications.

\section{Materials and methods}

Eighteen consecutive bushes in a single row of 20+-year-old 'Woodard' rabbiteye blueberry bushes were chosen to receive pruning renovation treatments on 14 July 2017 after harvest was completed. The bushes were grown at the United States Department of Agriculture (USDA), Agricultural Research Service (ARS), Thad Cochran Southern Horticultural Laboratory station in Poplarville, MS (lat. $30^{\circ} 85^{\prime} 36^{\prime \prime} \mathrm{N}$, long. $89^{\circ} 49^{\prime} 94^{\prime \prime} \mathrm{W}$, elevation $97 \mathrm{~m}$, USDA hardiness zone $8 \mathrm{~b}$ ). The soil type was Ruston fine sandy loam with $2 \%$ to $5 \%$ slopes. Bushes were spaced at $5 \mathrm{ft}$ between plants and $12 \mathrm{ft}$ between

\begin{tabular}{llll}
\hline $\begin{array}{l}\text { Units } \\
\begin{array}{l}\text { To convert U.S. to SI, } \\
\text { multiply by }\end{array}\end{array}$ & U.S. unit & SI unit & $\begin{array}{l}\text { To convert SI to U.S., } \\
\text { multiply by }\end{array}$ \\
\hline 0.3048 & $\mathrm{ft}$ & $\mathrm{m}$ & 3.2808 \\
2.54 & $\mathrm{inch}(\mathrm{es})$ & $\mathrm{cm}$ & 0.3937 \\
0.4536 & $\mathrm{lb}$ & $\mathrm{kg}$ & 2.2046 \\
1.1209 & $\mathrm{lb} / \mathrm{acre}$ & $\mathrm{kg} \cdot \mathrm{ha}^{-1}$ & 0.8922 \\
28.3495 & $\mathrm{oz}$ & $\mathrm{g}$ & 0.0353
\end{tabular}




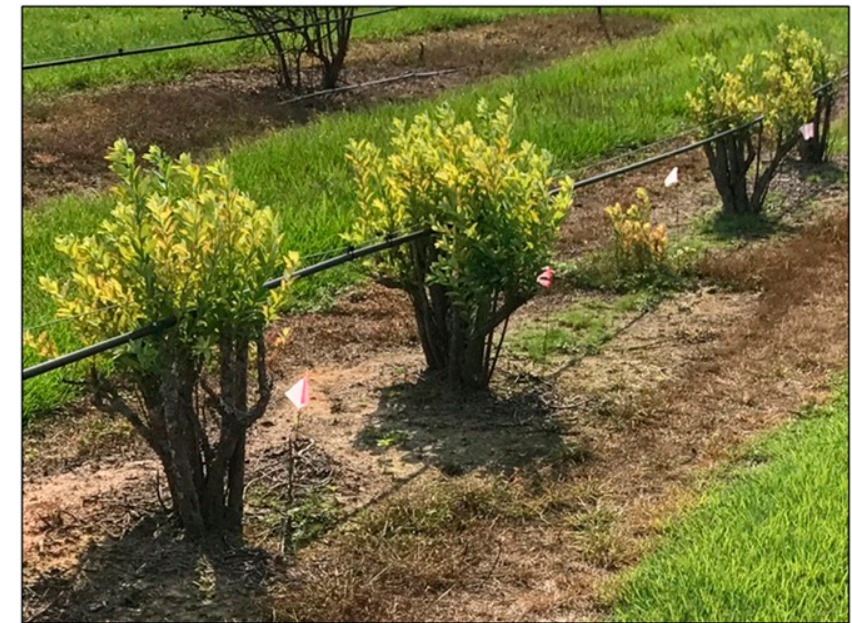

Fig. 1. Early regrowth in both ground level and 50-cm (19.7 inches) above ground level treatments on 'Woodard' rabbiteye bushes. Four bushes with visible stumps represent the $50-\mathrm{cm}$ above ground level treatment and the one ground level bush is in the middle.

Table 1. Fruit-related aspects of 'Woodard' rabbiteye blueberry bushes renovation pruned at two different heights. Harvest index was calculated by dividing fruit yield by cane weight from Table 2.

\begin{tabular}{|c|c|c|c|c|}
\hline Treatment & $\underset{\text { bush }^{\mathrm{z}}}{\text { Avg yield (kg/ }}$ & $\begin{array}{c}\text { Avg berry wt } \\
(\mathrm{g})^{\mathrm{z}}\end{array}$ & $\begin{array}{l}\text { Soluble solids } \\
\text { content }(\%)\end{array}$ & $\begin{array}{c}\text { Harvest } \\
\text { index }\end{array}$ \\
\hline \multicolumn{5}{|l|}{2019} \\
\hline $\begin{array}{c}50 \mathrm{~cm}(19.7 \\
\text { inches })\end{array}$ & $3.47 \mathrm{a}^{\mathrm{y}}$ & $1.27 \mathrm{a}$ & $\mathrm{NA}^{\mathrm{x}}$ & NA \\
\hline Ground level & $0.63 \mathrm{~b}$ & $1.32 \mathrm{a}$ & NA & NA \\
\hline$P$ value & 0.0001 & 0.66 & & \\
\hline \multicolumn{5}{|l|}{2020} \\
\hline $50 \mathrm{~cm}$ & $3.91 \mathrm{a}$ & $1.39 \mathrm{a}$ & $13.1 \mathrm{a}$ & $0.53 \mathrm{a}$ \\
\hline Ground level & $1.23 \mathrm{~b}$ & $1.41 \mathrm{a}$ & $13.5 \mathrm{a}$ & $0.19 \mathrm{~b}$ \\
\hline$P$ value & 0.002 & 0.69 & 0.83 & 0.001 \\
\hline
\end{tabular}

${ }^{\mathrm{z}} 1 \mathrm{~kg}=2.2046 \mathrm{lb}, \mathrm{l} \mathrm{g}=0.0353 \mathrm{oz}$.

${ }^{\mathrm{y}}$ Means not followed by the same letter within a column were deemed to be significantly different by Student's $t$ test at $P \leq 0.05$

${ }^{x} \mathrm{NA}=$ not available; soluble solids data were not collected in 2019 due to lack of available labor and the harvest index could not be calculated because cane weights, a destructive measurement, were not taken in 2019.

rows. Two pruning treatments were tested: bushes were cut either at ground level or at a $50-\mathrm{cm}$ above ground level (Fig. 1). No annual pruning was done after initial treatments. All plants were annually fertilized equivalent to a rate of $100 \mathrm{lb} /$ acre nitrogen. No fungicides or insecticides were applied during the study, but herbicide [glufosinate-ammonium (Rely 280; Bayer CropScience, Research Triangle Park, NC)] applications were performed as needed to control weeds.

Three phosphorous acid (AgriFos; AgBio, Loganholme, Queensland, Australia) treatments were tested as a potential biostimulant (Gomez-Merino and Trejo-Tellez,
2015) to improve and hasten regrowth. Drench and drench plus spray treatments of phosphorous acid were applied as described in Stafne and Smith (2019). Results from the first year showed no significant impact of using phosphite on yields or other factors, thus data for seasons 2 and 3 were combined across all phosphite treatments. Each renovation treatment had nine replications.

Data collected in 2019 and 2020 were plant yield, average berry weight, and plant health rating (a I to 10 visual scale). Soluble solids content, final cane number, and final cane weight were only measured in 2020. Assessment of final cane number and final cane weight were from destructive measurements done one time at the end of the study. Fruit was harvested once or twice weekly from late May to early July, then added together for a total yield per bush. Ten berries were randomly selected at each harvest, weighed, then divided by 10 to obtain an average berry weight. Soluble solids content was measured on a midseason 2020 harvest with a digital hand-held refractometer (3810 PAL-1; Atago, Osaka, Japan) after lightly hand-crushing 10 to 20 berries (based on the available number of berries) and then extracting the resulting juice.

Plant health ratings were performed by the first author visually after harvest was complete using a subjective scale where $1=$ very poor plant health and $10=$ excellent plant health. In 2020, all canes were destructively harvested from each bush, counted, and immediately weighed. The purpose of using fresh weight was to include all vegetative growth, including leaves. While dry weight is often considered more accurate, bushes in this study, aside from the pruning treatments, received the same level of management and environmental exposure. Harvest index was calculated by dividing fruit yield by cane weight (Price and Munns, 2018).

The growth index (GI) was calculated as $\mathrm{GI}=\mathrm{H}+[(\mathrm{L}+\mathrm{W}) / 2] / 2$, where $\mathrm{H}=$ bush height, $\mathrm{L}=$ bush length within a row, and $\mathrm{W}=$ bush width from row side to row side, as described by Irmak et al. (2004). The bushes were measured at the end of the harvest season before cane removal. The height of the bush was measured from the ground in the case of ground-level pruning and from the $50-\mathrm{cm}$ stump height in the $50-\mathrm{cm}$ above ground level treatment to the top of the tallest cane. For width and depth, the bushes were measured from widest cane to widest cane on each side of the bush.

Data were analyzed by JMP (version 12; SAS Institute, Cary, NC) using the Student's $t$ test. This test assumed equal variances using a pooled estimate to differentiate between the treatments at the $95 \%$ confidence interval.

\section{Results and discussion}

There were no differences related to phosphorous acid treatments 
Table 2. Vegetative growth-related components of 'Woodard' rabbiteye blueberry bushes renovation pruned at two different heights. Plant health ratings were performed visually after harvest was complete using a subjective scale where 1 = very poor plant health and $10=$ excellent plant health. The growth index $(\mathrm{GI})$ was calculated as $\mathrm{GI}=\mathrm{H}+[(\mathrm{L}+\mathrm{W}) / 2] / 2$, where $\mathrm{H}=$ bush height, $\mathrm{L}=$ bush length within a row, and $\mathrm{W}=$ bush width from row side to row side.

\begin{tabular}{lcccc}
\hline Treatment & $\begin{array}{c}\text { Plant health rating } \\
(\mathbf{1}-\mathbf{1 0})\end{array}$ & GI & Canes (no.) & Cane wt $(\mathbf{k g})^{\mathbf{z}}$ \\
\hline 2019 & & & & \\
$50 \mathrm{~cm}(19.7$ inches $)$ & $7.1 \mathrm{a}^{\mathrm{y}}$ & $64.1 \mathrm{a}$ & $\mathrm{NA}^{\mathrm{x}}$ & $\mathrm{NA}$ \\
$\quad$ Ground level & $5.9 \mathrm{~b}$ & $54.9 \mathrm{~b}$ & $\mathrm{NA}$ & $\mathrm{NA}$ \\
$P$ value & 0.04 & 0.01 & & \\
2020 & & & & \\
$50 \mathrm{~cm}$ & $6.6 \mathrm{a}$ & $61.6 \mathrm{a}$ & $32.6 \mathrm{a}$ & $6.9 \mathrm{a}$ \\
Ground level & $6.2 \mathrm{a}$ & $62.8 \mathrm{a}$ & $17.8 \mathrm{~b}$ & $5.6 \mathrm{a}$ \\
$P$ value & 0.35 & 0.60 & 0.001 & 0.16 \\
\hline
\end{tabular}

${ }^{\mathrm{z}} 1 \mathrm{~kg}=2.2046 \mathrm{lb}$.

'Means not followed by the same letter within a column were deemed to be significantly different by Student's $t$ test at $P \leq 0.05$.

${ }^{\mathrm{x}} \mathrm{NA}=$ not available; these data were not collected in 2019 because it was a one-time destructive measurement.

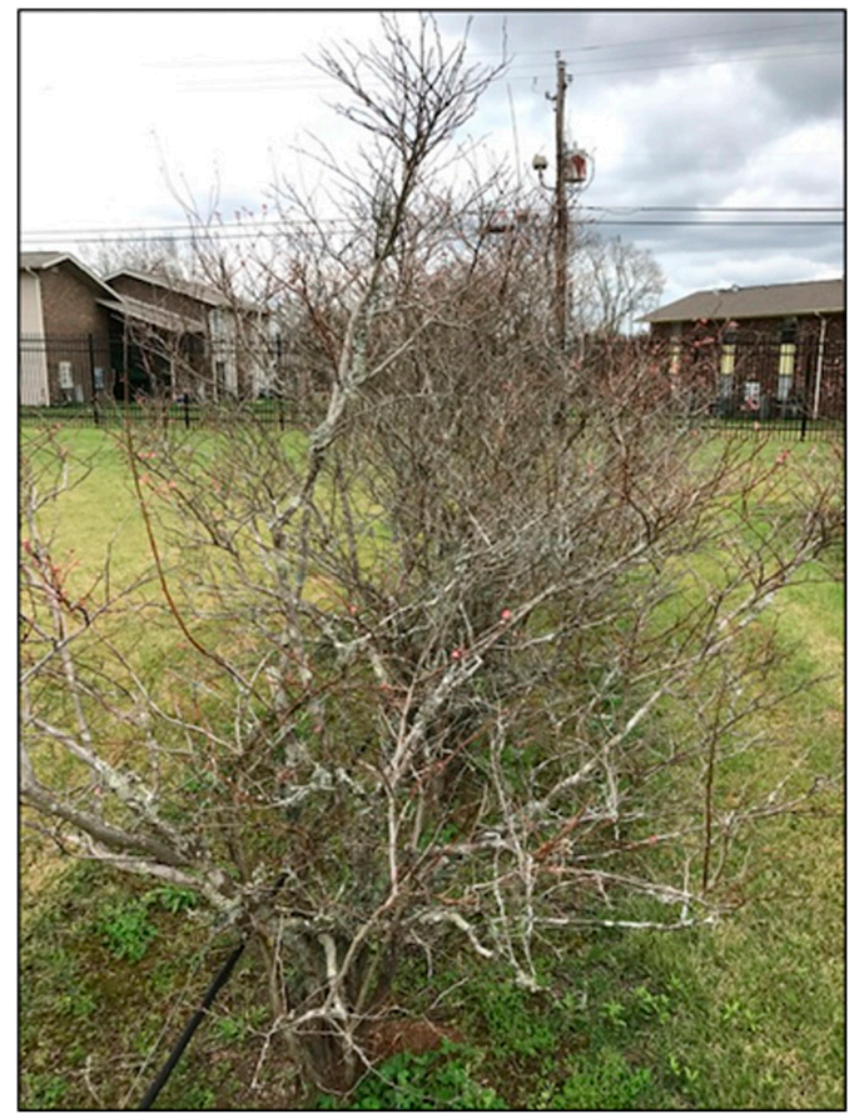

Fig. 2. A representative 'Woodard' rabbiteye blueberry bush within the same row as the treatment bushes during the dormant season before renovation pruning.

in any data evaluated in this study. Due to their lack of effect, especially on yield per plant in the first year $(P=0.95)$, we decided to eliminate the treatment from the study in subsequent years. Therefore, the phosphorous acid treatments were discontinued after the initial year, and data were combined across all phosphite treatments for years 2 and 3. All first-year data collected post-treatment were reported by Stafne and Smith (2019).
Pruning at the $50-\mathrm{cm}$ above ground level vs. ground level provided a substantial yield benefitwhile having no difference in most other measured parameters (Table 1). Yields were much higher every year post-treatment, including the first year (Stafne and Smith, 2019). In years 2 and 3 following treatment, the $50-\mathrm{cm}$ above ground level treatment yielded on average nearly 3.5 and $4.0 \mathrm{~kg} / \mathrm{bush}$, respectively. These amounts are equivalent to 5590 and $6402 \mathrm{lb} /$ acre, close to or within the range of normal annual Mississippi rabbiteye blueberry production of 6000 to $10,000 \mathrm{lb} /$ acre (Stafne et al., 2020). However, the ground level treatment yields were much less; and, even by year 3 , these had not yet reached acceptable, average production yields. Therefore, leaving a short stump of $50 \mathrm{~cm}$ provided an early benefit in terms of rabbiteye blueberry fruit production, like the research reported by Austin and Brightwell (1984). Randle (2018) employed a different method of plant rejuvenation on a different cultivar (Tifblue) but found that yields rebounded by the second year following pruning at ground level. In the present study, bushes pruned at ground level did not respond as quickly as in the study by Randle (2018), suggesting that other factors such as cultivar, location, management, and initial plant health play roles in the return to productivity.

Berry weights did not differ between treatments in either 2019 or 2020. While the $50-\mathrm{cm}$ above ground level treatment had more canes and greater overall yield, these factors did not affect berry size (Table 1). Soluble solids content was only measured in 2020 and did not differ between treatments. The harvest index, a measure of reproductive to vegetative growth ratio, measured in 2020 showed a higher value for the $50-\mathrm{cm}$ above ground level treatment. A higher value is more desirable for the producer and indicative of higher fruiting potential. The low harvest index value of the ground level treatment suggested that necessary energy was directed toward vegetative aboveground growth features (new canes and leaves) instead of reproductive (fruit) production (Table 1 ).

The GI is a measure used to compare the size of plants grown 
under different conditions, in this case two renovation pruning heights. In 2020, the GI for the 50-cm above ground level and ground level pruning cuts were not significantly different (Table 2), but the $50-\mathrm{cm}$ above ground level treatment was larger in 2019. The overall sizes of the ground level treatment bushes caught up to the $50-\mathrm{cm}$ above ground level treatment by the third growing seasons after renovation pruning.

The number of canes produced differed considerably by treatment (Table 2). Bushes pruned at the 50$\mathrm{cm}$ above ground level averaged 32.6 canes, whereas the ground level pruned bushes averaged 17.8 canes. This difference could be attributed to the number of latent buds within the remaining stumps of the $50-\mathrm{cm}$ above ground level treatment that emerged and produced canes that bore fruit, which is common in rabbiteye blueberry plants (Lockwood, 1999). Interestingly though, when the canes were weighed, the treatments were not significantly different (Table 2).

Plant health ratings were assessed on a 1 to 10 scale, where the higher rating means a bush has the appearance of good health, based on new growth, disease presence, leaf color, and other factors that could be an indicator of health. The treatments were significantly different in 2019 , but not in 2020. Numerically, ratings for the ground level pruning treatment were lower in both years (Table 2). Therefore, the appearance of the bushes for each treatment were similar by the third season after treatments were applied.

\section{Conclusions}

Moribund, aged rabbiteye bushes are widespread throughout Mississippi and much of the southern U.S., and thus renovation pruning is a necessary management strategy. In this study, bushes pruned at a $50-\mathrm{cm}$ height above ground level produced more canes and more fruit than bushes pruned at ground level. While it stands to reason that removing all old wood might be the best course of action due to potential existing pest issues, this may not be necessary in rabbiteye blueberries when damaging pests are absent. The bushes in this study were in very poor health before renovation (Fig. 2); and while they still produced fruit, production was less than desirable in total yield and quality. Based on the results of this study, leaving a $50-\mathrm{cm}$-tall stump when applying a renovation pruning will lead to earlier and higher yields than cutting back to the ground level. Therefore, while this study did not test all possible pruning height and cultivar combinations, any recommendation for rabbiteye blueberry pruning renovation in Mississippi going forward will be to leave at least 50 $\mathrm{cm}$ of the old canes and not to remove them at ground level.

\section{Literature cited}

Austin, M.E. and W.T. Brightwell. 1984. Rejuvenating rabbiteye blueberry 'Tifblue' and 'Woodard'. J. Amer. Soc. Hort. Sci. 109:74-77.

Gomez-Merino, F.C. and L.I. Trejo-Tellez. 2015. Biostimulant activity of phosphite in horticulture. Scientia Hort. 196:82-90, doi: 10.1016/j.scienta.2015.09.035.

Irmak, S., D.Z. Haman, A. Irmak, J.W Jones, K.L. Campbell, and T.L. Crisman. 2004. Measurement and analysis of growth and stress parameters of Viburnum odoratissimum (Ker-gawl) grown in a multi-pot box system. HortScience 39:1445-1455, doi: 10.21273/HORTSCI.39.6.1445.

Lockwood, D. 1999. Pruning blueberries. Univ. Tennessee Agr. Ext. Serv. SP284-E. 25 Jan. 2021. <https:// extension.tennessee.edu/publications/ documents/sp284-e.pdf>.

Longstroth, M. 2015. Revitalize blueberries with renovation. 16 Dec. 2020. <http://msue.anr.msu.edu/news/ revitalize_blueberries_with_renovation $>$.
Lovatt, C.J. 1999. Timing citrus and avocado foliar nutrient applications to increase fruit set and size. HortTechnology 9:607-612, doi: 10.21273/HORTTECH.9.4.607.

Lovatt, C.J. 2013. Properly timing foliarapplied fertilizers increases efficacy: A review and update on timing foliar nutrient applications to citrus and avocado. HortTechnology 23:536-541, doi: 10.21273/ HORTTECH.23.5.536.

Price, C. and R. Munns. 2018. Chapter 6Growth analysis: A quantitative approach. In: R. Munns, S. Schmidt, C. Beveridge, and U. Mathesius (eds.). Plants in action. 24 Nov. 2020. <https://www.asps.org.au/wpcontent/uploads/Chapter-6-growthanalysis-for-PDF.pdf>.

Randle, A. 2018. Application of rejuvenation pruning in mature rabbiteye blueberries (Vaccinium ashei). J. NACAA 11(1). 24 Nov. 2020. <https://www. nacaa.com/journal/index.php?jid=793 $>$.

Rickard, D.A. 2000. Review of phosphorous acid and its salts as fertilizer materials. J. Plant Nutr. 23:161-180, doi: 10.1080/ 01904160009382006.

Stafne, E.T. and B.J. Smith. 2019. Effect of phosphorous acid and pruning height on renovated 'Woodard' rabbiteye blueberry. Proc. North American Blueberry Res. Ext. Workers Conf. 12-15 Aug. 2018, Orono, ME. 24 Nov. 2020. <https://digitalcommons.library. umaine.edu/cgi/viewcontent.cgi? article $=1001 \&$ context $=$ nabrew2018 $>$.

Stafne, E.T., R.A. Melanson, B. Layton, J.L. Silva, and E. Canales. 2020. Establishment and management of blueberries. Mississippi State Univ. Coop. Ext. Serv. Pub. 1758. 15 Dec. 2020. <http:// extension.msstate.edu/publications/ publications / establishment-andmaintenance-blueberries $>$.

Thao, H.T.B. and T. Yamakawa. 2009. Phosphite (phosphorous acid): Fungicide, fertilizer, or bio-stimulator? Soil Sci. Plant Nutr. 55:228-234, doi: 10.1111/ j.1747-0765.2009.00365.x. 